\title{
THE COMPOST, A SOURCE OF PLANT BENEFICIAL BACTERIA WITH BIOCONTROL POTENTIAL
}

\author{
Oana-Alina Boiu-Sicuiaa ${ }^{1,2 *}$, Vasilica $\operatorname{Stan}^{3}$, Călina Petruța Cornea ${ }^{1}$ \\ ${ }^{1}$ University of Agronomic Sciences and Veterinary Medicine - Bucharest, Faculty of Biotechnology, \\ 59 Mărăști Blvd., Bucharest, Romania \\ ${ }^{2}$ Research-Development Institute for Plant Protection, 8 Ion Ionescu de la Brad Blvd., Bucharest, Romania \\ ${ }^{3}$ University of Agronomic Sciences and Veterinary Medicine of Bucharest, Faculty of Agriculture, \\ 59 Mărăști Blvd., Bucharest, Romania
}

\begin{abstract}
Recycling the sewage sludge from treatment plants is a common activity. The resulting compost is usually rich in plant nutrients and beneficial microorganisms. However, compost properties greatly differ depending on the nature of the fermented biomass and fermentation processes. The aim of this study was to analyze the microbial load of three different composts, in order to detect new bacterial strains with plant protection properties. Isolated bacteria were microbiologically characterized and evaluated for their potential to reduce soil-borne phytopathogenic fungi. Results showed a microbial load of approximately $10^{6} \mathrm{CFU} / \mathrm{g}$ of compost. In the analyzed samples it was revealed that as bacterial load increases, the fungal amount decreases. Analyzing some newly isolated bacteria obtained from these composts, a good biocontrol potential against soil-borne pathogenic fungi was revealed. Some of the isolated bacterial strains revealed antifungal activity against Rhizoctonia solani and Sclerotinia sclerotiorum. These bacteria showed good colonization capacity and lytic enzymes production, correlated to antimicrobial activity. These compost-originated bacteria reveal high potential in pathogens inhibition. Therefore, the analyzed composts are recommended not only as soil fertility improvers, but also as potential suppressors of soil-borne pathogens. Results revealed these composts as source of plant beneficial bacteria with biological control potential.
\end{abstract}

Keywords: biocontrol, compost, plant-beneficial bacteria.

\section{INTRODUCTION}

Urbanization expansion involves increased amounts of wastewater which trigger serious environmental problems regarding its disposal (Dușa et al., 2020). Responsible waste management fulfills the wastewater treatment plants and increases the amount of resulting sewage sludge (SS) (Bożym and Siemiątkowski, 2018). As SS contain an imbalanced plant nutrient rate, especially high amounts on nitrogen, it could harm the soil-plant system if incorrectly used (Moretti et al., 2015). Furthermore, the SS can deliver potentially toxic elements, such as pharmaceuticals, hormones, heavy metals, as well as pathogens (Raheem et al., 2017).

For sustainable agricultural use, some recommend that SS should be improved with structural materials, such as chopped wood, plant debris or coal, before composting or vermicomposting (Moretti et al., 2015; Kebibeche et al., 2019; Dușa et al., 2020). The resulting compost or 


\begin{tabular}{l}
\hline $\begin{array}{c}\text { Current Trends in Natural Sciences } \\
\text { Vol. 10, Issue 20, pp. 32-38, 2021 } \\
\text { https://doi.org/10.47068/ctns.2021.v10i20.004 }\end{array}$ \\
$\begin{array}{l}\text { Current Trends in Natural Sciences (CD-Rom) } \\
\text { ISSN: 2284-953X }\end{array}$ \\
$\begin{array}{ll}\text { ISSN: 2284-9521 } \\
\text { ISSN-L: 2284-9521 }\end{array}$ \\
ISSN-L: 2284-9521 \\
\hline
\end{tabular}

vermicompost reveal good properties as soil fertilizer and reduces the risks of environmental contamination compared to the SS by reducing nitrate leaching, converting nitrogen from nitrate and ammonia to more stable organic forms that are slowly released to crops (Corrêa et al., 2006), concentrating phosphorous and other plant nutrients, or decreasing the pathogenic microbial load (Khalil et al., 2011).

The aim of this study was to analyze the microbial load of three different composts, in order to detect new bacterial strains with plant protection properties. This study is a continue of Dușa et al. (2020) research regarding compost quality improvement of SS by vermicomposting.

\section{MATERIALS AND METHODS}

Three compost samples were used in this study, all resulting from SS's from Pitești and Mioveni, and enriched with Eisenia sp. earthworms collected from a pile of plant debris from USAMV Bucharest.

Microbial load in each compost was analyzed by serial dilution and agar plating techniques. The quantification was separately made for bacteria and fungi.

The composts were also used to prepare 3 week old compost teas (figure 1). Therefore, $10 \mathrm{~g}$ of compost were immersed in sterile distilled water in 1:5 (w/v) ratios, and the suspension was subjected to $200 \mathrm{rpm}$ shaking. The resulting homogenates, infused for 21 days, were filtered through Wattman no.1 paper in order to collect the compost teas.
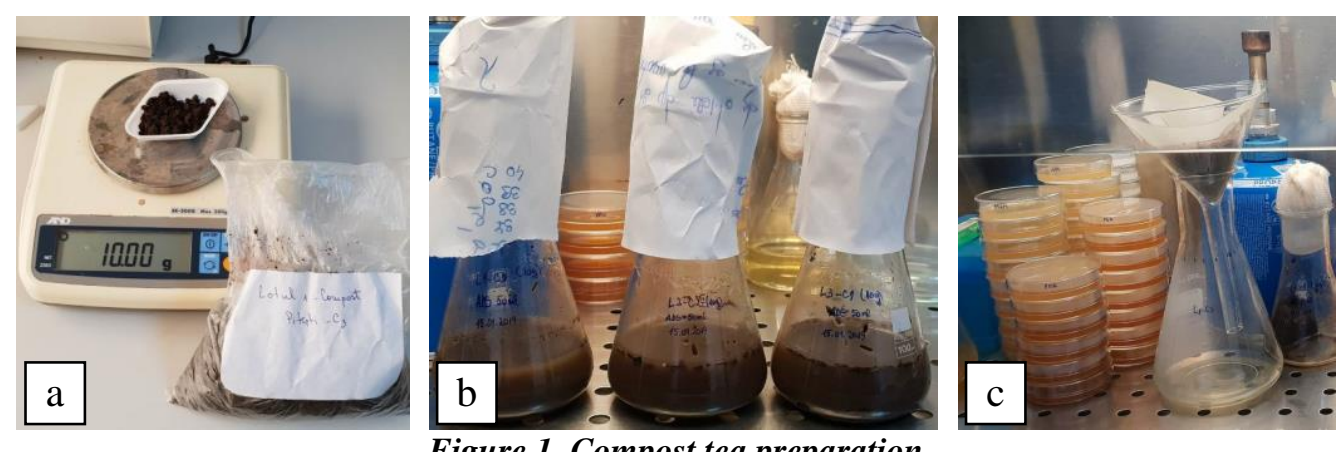

Figure 1. Compost tea preparation

a. compost weighing, b. tree week old compost infusion, c. compost tea filtration

The compost teas were used to evaluate if their microbial load contain plant beneficial microorganisms against common agricultural pathogenic fungi such as Botrytis cinerea, Fusarium oxysporum, Fusarium sp., Rhizoctonia solani, Sclerotium bataticola and Sclerotinia sclerotiorum. For this purpose, $90 \mathrm{~mm}$ diameter plates were loaded with Potato-Dextrose-Agar and spread-plated with $100 \mu \mathrm{l}$ of compost tea. These plates were than inoculated with mycelia plugs $(7 \mathrm{~mm})$ of phytopathogenic fungi, collected from 7 days old pure cultures. After 10 days of incubation at $26^{\circ} \mathrm{C}$ bacterial colonies with antifungal activity were selected and purified by repetitive streaking technique on Luria Bertani agar.

Newly isolated bacterial strains were analyzed for Gram stain reaction and microbial motility, such as swarming and swimming, according to Popa et al (2017). For swarming motility each bacterial strain was inoculated in the middle of a Petri plate of $7 \mathrm{~cm}$ diameter, on Luria Bertani with $0.5 \%$ agar, in triplicate. Similar, the swimming motility was evaluated on Luria Bertani with $0.3 \%$ agar. The motility test was considered positive if the bacteria were able to colonize the surface of the plates in the first $24 \mathrm{~h}$ of incubation. Lytic enzymes production was also analyzed to evaluate 
bacterial potential to produce chitinase, carboxymethyl cellulase, and caseinase (Sicuia et al., 2015). Chitinolytic activity was evaluated on a $\mathrm{pH}$ sensitive medium containing $0.45 \%$ colloidal chitin, $0.3 \% \mathrm{MgSO}_{4} \cdot 7 \mathrm{H}_{2} \mathrm{O}, 0.3 \%\left(\mathrm{NH}_{4}\right)_{2} \mathrm{SO}_{4}, 0.2 \% \mathrm{~K}_{2} \mathrm{HPO}_{4}, 0.1 \%$ citric acid citric, $0.015 \%$ bromocresol purple, $0.2 \%$ ( $/ \mathrm{v} / \mathrm{v})$ tween 80 and $2 \%$ agar, at $\mathrm{pH} 4.5$. The reaction was considered positive if the bacterial strains degraded the colloidal chitin to $\mathrm{N}$-acetyl glucosamine and the $\mathrm{pH}$ indicator dye changed the substrate color from yellow to purple. Cellulolytic activity was evaluated on carboxymethyl cellulose (CMC) medium containing $0.05 \% \quad \mathrm{NaCl}, \quad 0.1 \% \quad \mathrm{~K}_{2} \mathrm{HPO}_{4}, 0.05 \%$ $\mathrm{MgSO}_{4} \cdot 7 \mathrm{H}_{2} \mathrm{O}, 0.001 \% \mathrm{MnSO}_{4} \cdot \mathrm{H}_{2} \mathrm{O}, 0.03 \% \mathrm{~g} \mathrm{NH}_{4} \mathrm{NO}_{3}, 0.001 \% \mathrm{FeSO}_{4} \cdot 7 \mathrm{H}_{2} \mathrm{O}, 1 \% \mathrm{CMC}$, and $1.2 \%$ agar, at $\mathrm{pH} 7.0 \pm 0.2$. Positive reactions were revealed by the clear hallo around the enzyme producing strains, only after incubation, treatment with $0.1 \%$ Congo red and rinsing with $1 \mathrm{M} \mathrm{NaCl}$. Casein degrading ability was evaluated on Skim Milk agar (VWR International GmbH). Bacterial isolates were also subjected to Voges-Proskauer reaction to evaluate acetoin production, a volatile organic compound (VOC) also known as acetyl methyl carbinol or 3-hydroxy-2-butanone.

The antifungal potential was evaluated by dual culture technique. Tests were performed in vitro against two soil-borne phytopatogenic fungi, Rhizoctonia solani and Sclerotinia sclerotiorum. The inhibition efficacy was calculated compared to the fungal growth in the control plates, as follows:

$$
\mathrm{E} \%=(1-\mathrm{T} / \mathrm{C}) * 100
$$

were: $\mathrm{E}$ - is the efficacy of tested inhibitor (bacterial strain or compost tea), $\mathrm{T}$ - is the diameter of the fungal colony in the test plates, and $\mathrm{C}$ - diameter of the fungal colony in the control plates.

\section{RESULTS AND DISCUSSIONS}

Composts microbial load was rich in both bacteria and fungi. The microbial community was approximated at $10^{6} \mathrm{CFU} / \mathrm{g}$ of compost (table 1). In the analyzed samples it was revealed that as bacterial load increases, the fungal amount decreases.

Table 1. Compost microbial load

\begin{tabular}{|l|c|c|}
\hline \multirow{2}{*}{ Compost teas } & \multicolumn{2}{|c|}{ Microbial colonies/ gram of compost teas } \\
\cline { 2 - 3 } & Bacteria & Fungi \\
\hline SS_1M & $1.45 \times 10^{6}$ & $1.2 \times 10^{5}$ \\
\hline SS_2M & $1.83 \times 10^{6}$ & $8.5 \times 10^{4}$ \\
\hline SS_P & $1.72 \times 10^{6}$ & $7.7 \times 10^{4}$ \\
\hline
\end{tabular}

By spread-plating the compost teas against various agricultural pathogens good antifungal activity was observed. The inhibition was more evident against some of the pathogens, compared to Fusarium species (table 2). Results revealed these composts as source of plant beneficial bacteria with biological control potential.

Table 2. Antifungal activity of the compost teas

\begin{tabular}{|l|c|c|c|c|c|c|}
\hline \multirow{2}{*}{$\begin{array}{c}\text { Compost } \\
\text { teas origin }\end{array}$} & $\begin{array}{c}\text { Botrytis } \\
\text { cinerea }\end{array}$ & $\begin{array}{c}\text { Fusarium } \\
\text { oxysporum }\end{array}$ & $\begin{array}{c}\text { Fusarium } \\
\text { sp. }\end{array}$ & $\begin{array}{c}\text { Rhizoctonia } \\
\text { solani }\end{array}$ & $\begin{array}{c}\text { Sclerotium } \\
\text { bataticola }\end{array}$ & $\begin{array}{c}\text { Sclerotinia } \\
\text { sclerotiorum }\end{array}$ \\
\cline { 2 - 7 } & \multicolumn{7}{|c|}{ Fungal inhibition efficacy (\%) } \\
\hline SS_1M & 82.2 & 60.1 & 55.0 & 67.4 & 87.5 & 67.3 \\
\hline SS_2M & 82.2 & 60.1 & 52.5 & 67.4 & 87.5 & 76.9 \\
\hline SS_P & 75.6 & 48.3 & 50.0 & 61.2 & 68.8 & 70.8 \\
\hline
\end{tabular}




\section{Current Trends in Natural Sciences}

Vol. 10, Issue 20, pp. 32-38, 2021

https://doi.org/10.47068/ctns.2021.v10i20.004

Current Trends in Natural Sciences (on-line)

ISSN: 2284-953X

Current Trends in Natural Sciences (CD-Rom)

ISSN: 2284-9521

ISSN-L: 2284-9521

ISSN-L: 2284-9521

The inhibition was mostly triggered by microbial competition. As the microorganisms from the compost teas colonized the surface of the substrate the pathogens growth was reduced.

In the microbial communities of the compost teas, some microorganisms revealed higher inhibitory activity (figure 2) and therefor they were collected and purified, obtaining six pure isolates.

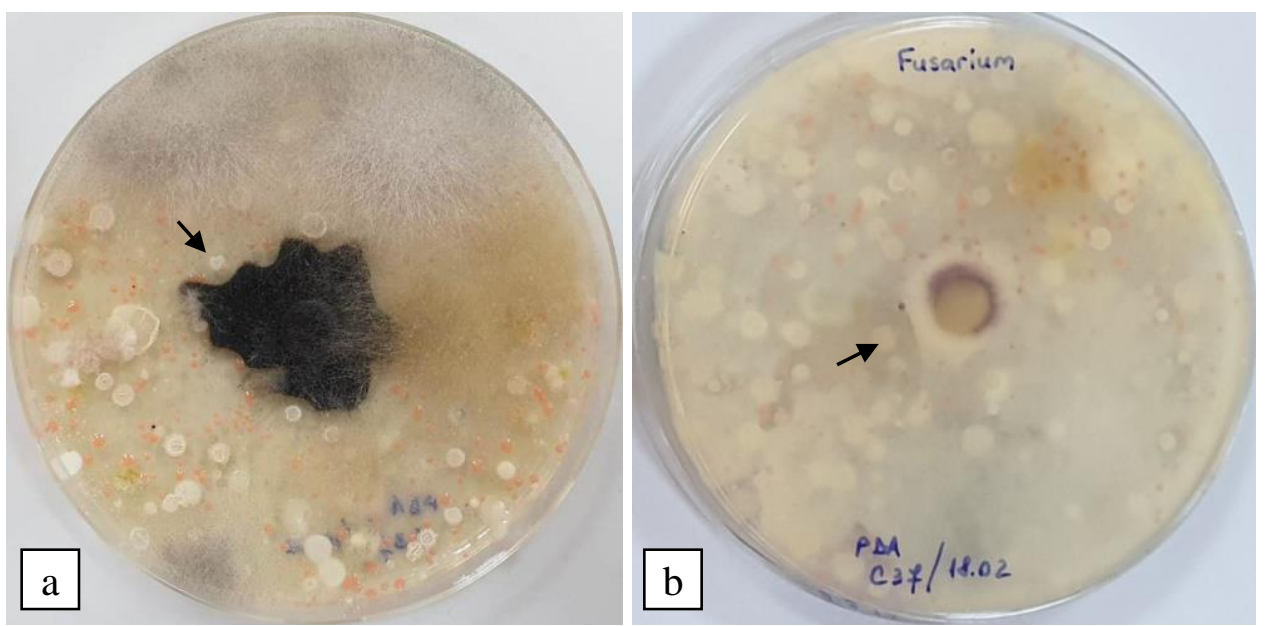

Figure 2. Bacterial selection before isolation and purification

- bacterial colony antagonistic to Sclerotium bataticola (a) and Fusarium sp. (b) -

All these isolates were revealed as Gram positive, rod shaped, with single cells arrangement or in pairs. Although the community from where they were extracted showed good colonization capacity, when purified only two strains (C2 and C6) maintained this properties. Bacterial motility improves the colonization capacity of the strains. Swimming motility is correlated with single cells movement, and facilitates bacterial spread in the environment. Swarming motility also involves bacterial colonization, but refers to cells aggregation and adhesion to different surfaces, in correlation with biofilm formation and intercellular communication inside population.

When analyzed for lytic enzymes production different abilities were revealed. The $\mathrm{C} 4$ isolate showed chitinolytic activity and C1, C2, C5, C6 expressed cellulolytic activity (figure 3). Proteolysis was seen to all isolates, with a higher enzymatic activity expressed by C2, C3 and C6 strains (table 3). These three strains revealed clear hallo of casein hydrolysis of $14 \mathrm{~mm}$ around their colonies (figure 3 ).

Table 3. Bacteria characterization

\begin{tabular}{|c|c|c|c|c|c|c|}
\hline \multirow{2}{*}{$\begin{array}{l}\text { Bacterial } \\
\text { isolates }\end{array}$} & \multicolumn{2}{|c|}{ Bacterial motility } & \multirow{2}{*}{$\begin{array}{c}\text { Chitinolytic } \\
\text { activity }\end{array}$} & \multirow{2}{*}{$\begin{array}{l}\text { Cellulase } \\
\text { activity }\end{array}$} & \multirow{2}{*}{$\begin{array}{l}\text { Protease } \\
\text { activity }\end{array}$} & \multirow{2}{*}{$\begin{array}{c}\text { Acetoin } \\
\text { production }\end{array}$} \\
\hline & swimming & swarming & & & & \\
\hline $\mathrm{C} 1$ & - & - & - & $+6 \mathrm{~mm}$ & + & + \\
\hline $\mathrm{C} 2$ & + & + & - & $+6 \mathrm{~mm}$ & $+14 \mathrm{~mm}$ & + \\
\hline C3 & - & - & - & - & $+14 \mathrm{~mm}$ & + \\
\hline $\mathrm{C} 4$ & - & - & $+6 \mathrm{~mm}$ & - & $+6 \mathrm{~mm}$ & + \\
\hline $\mathrm{C} 5$ & - & - & - & $+9 \mathrm{~mm}$ & + & untested \\
\hline C6 & + & + & - & $+7 \mathrm{~mm}$ & $+14 \mathrm{~mm}$ & untested \\
\hline
\end{tabular}




\section{Current Trends in Natural Sciences}

Vol. 10, Issue 20, pp. 32-38, 2021

https://doi.org/10.47068/ctns.2021.v10i20.004

Current Trends in Natural Sciences (on-line)

ISSN: 2284-953X

Current Trends in Natural Sciences (CD-Rom)

ISSN: 2284-9521

ISSN-L: 2284-9521

ISSN-L: 2284-9521

These studied enzymes are involved in fungal cell lysis, contributing to fungal antagonism along with other antagonistic mechanisms, such as microbial competition and production of volatile organic compounds. Regarding acetoin production tested strains, C1, C2, C3 and C4 revealed positive reaction showing a reddish layer on top of the broth culture. The acetoin is a volatile organic compound involved in plant protection and plant growth stimulation (Wu et al., 2019).

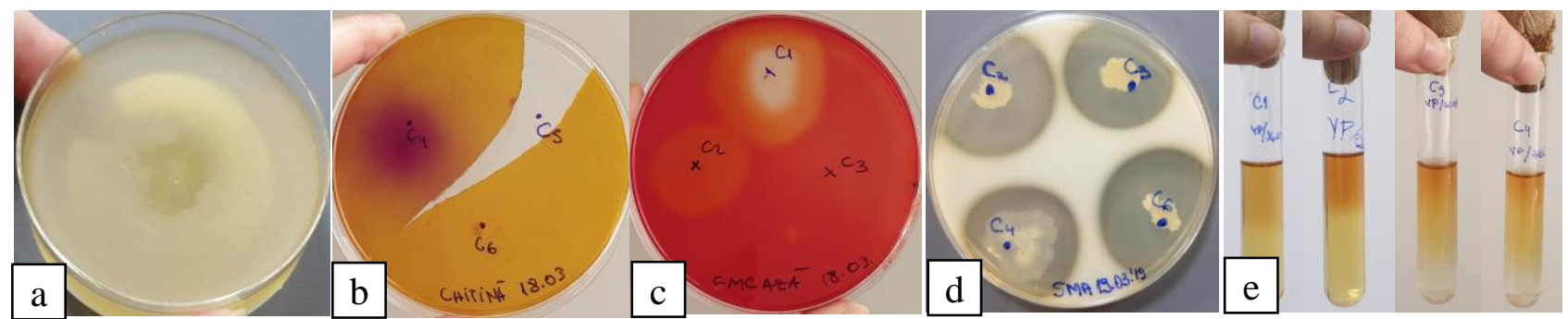

Figure 3. Bacterial physiologic properties

- swarming motility (a), chitinase (b), cellulose (c), protease (d) and acetoin (e) production -

differences were noticed regarding the antifungal activity when the compost-originated bacteria were tested as pure strains against plant pathogenic fungi. Although C3 isolate was selected from a community antagonistic to soil-borne fungi, when tested as pure, single strain could not inhibit Rhizoctonia solani and Sclerotinia sclerotiorum growth (figure 4).
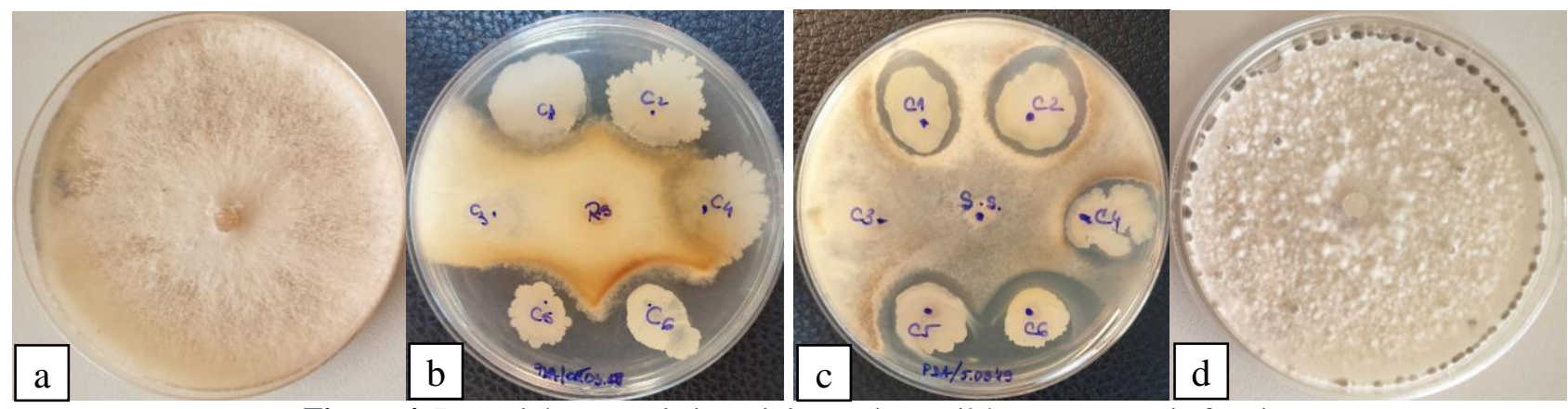

Figure 4. Bacterial antagonistic activity against soil-borne patogenic fungi:

$R$. solanii control plate (a), R. solanii growth inhibition (b), S. sclerotiorum growth inhibition (c) and S. sclerotiorum control plate $(\mathrm{d})$

The other pure strains $(\mathrm{C} 1, \mathrm{C} 2, \mathrm{C} 4, \mathrm{C} 5$ and $\mathrm{C} 6)$ maintained their antifungal capacity when tested against plant pathogenic fungi (figure 5).

As it is sown in figure 5, all bacterial isolates, beside $\mathrm{C} 3$, were able to inhibit tested soil-borne phytopathogenic fungi $R$. solani and $S$. sclerotiorum. Among isolated bacteria, C6 strain showed the highest biocontrol activity with an antifungal efficacy of $60.5 \%$ against $R$. solani and $62.8 \%$ against $S$. sclerotiorum. This bacterium being followed by $\mathrm{C} 2$ strain that revealed an antifungal efficacy of $60.5 \%$ against $R$. solani and $62.8 \%$ against $S$. sclerotiorum.

Analyzing under the light microscope the fungal growth in the presence of antagonistic bacteria, lysed fungal cells were observed to the edge of the colony, cells from which the cytoplasmic content was purring (figure 6). 

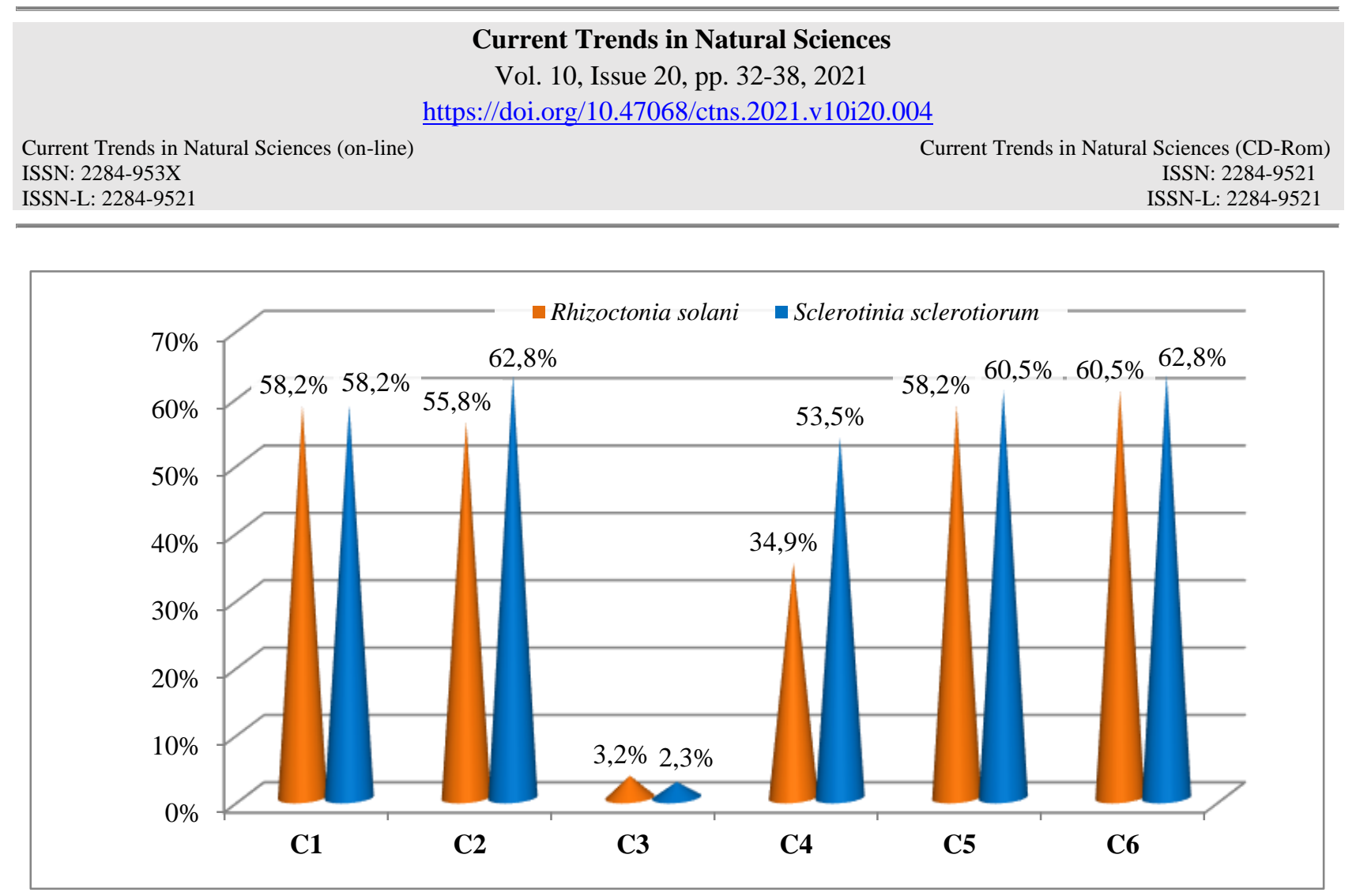

Figure 5. Fungal inhibition efficacy of the purified beacterial strains originated from compost teas

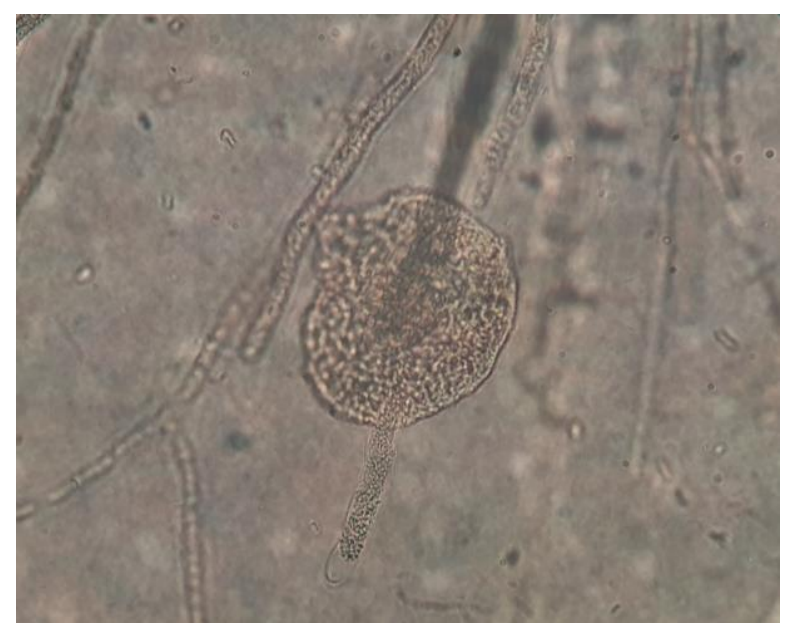

Figure 6. Fungal cell lysis due to the interaction with antagonistic bacteria showing lytic enzymes activity.

Similar results were described by Boiu-Sicuia et al. (2018) in other fungal-bacteria interaction, were fungal cell wall and membrane were degraded and leakages of the cytoplasmic content were seen.

\section{CONCLUSIONS}

The analyzed composts were revealed as source of plant beneficial bacteria with biological control potential. Therefore, they are recommended not only as soil fertility improvers, but also as potential suppressors of soil-borne pathogens.

Among isolated bacteria, best results were obtained with $\mathrm{C} 2$ and C6 strains which revealed various antagonistic mechanisms and antifungal traits, showing 58.2 to $60.5 \%$ efficacy against $R$. solani and $62.8 \%$ efficacy against $S$. sclerotiorum. 


\section{Current Trends in Natural Sciences}

Vol. 10, Issue 20, pp. 32-38, 2021

https://doi.org/10.47068/ctns.2021.v10i20.004

Current Trends in Natural Sciences (on-line)

ISSN: 2284-953X

Current Trends in Natural Sciences (CD-Rom)

ISSN: 2284-9521

ISSN-L: 2284-9521

ISSN-L: 2284-9521

\section{ACKNOWLEDGEMENTS}

This research was funded by the University of Agronomic Sciences and Veterinary Medicine of Bucharest.

\section{REFERENCES}

Boiu-Sicuia, O.A., Constantinescu, F., Diaconu, A., Drăghici, R. (2018). Current status and future perspectives in Romania on biological control of sweet potato fungal pathogen. Muzeul Olteniei Craiova. Oltenia. Studii şi comunicări. Ştiinţele Naturii, 34(2), 172-179.

Bożym, M., Siemiątkowski, G. (2018). Characterization of composted sewage sludge during the maturation process: a pilot scale study. Environ. Sci. Pollut. Res., 25, 34332-34342. https://doi.org/10.1007/s11356-018-3335-x.

Corrêa, R.S., White, R.E., Weatherley, A.J. (2006). Effect of compost treatment of sewage sludge on nitrogen behavior in two soils. Waste Management, 26, 614-619.

Duşa, M.E., Vrînceanu, N., Negru, P., Safta, E., Stan, V. (2020). Improving sewage sludge compost quality by vermicomposting. Scientific Papers. Series A. Agronomy, LXIII (2), 267-272.

Khalil, A.I., Hassouna, M.S., El-Ashqar, H.M.A., Fawzi, M. (2011). Changes in physical, chemical, and microbial parameters during the composting of municipal sewage sludge. World Journal of Microbiology and Biotechnology, 27, 2359-2369.

Kebibechea, H., Khelilb, O., Kacema, M., Harchea, M.K. (2019). Addition of wood sawdust during the co-composting of sewage sludge and wheat straw influences seeds germination. Ecotoxicology and Environmental Safety, 168, 423-430. https://doi.org/10.1016/j.ecoenv.2018.10.075

Moretti, S.M.L., Bertoncini, E.I., Abreu, C.H. Jr. (2015). Composting sewage sludge with green waste from tree pruning. Sci. Agric., 72(5), 432-439.

Popa, D.G., Boiu-Sicuia, O.A., Dudoiu, R. (2017). Plant beneficial bacterial strain with phc decontaminating potential. Proceedings of the VIII International Agricultural Symposium ,AGROSYM 2017“, 631(082), 1816-1821.

Raheem, A., Sikarwar, V.S., He, J., Dastyar, W., Dionysiou, D.D., Wang, W., Zhao M. (2018). Opportunities and challenges in sustainable treatment and resource reuse of sewage sludge: A review. Chemical Engineering Journal, 337, 616-641, https://doi.org/10.1016/j.cej.2017.12.149.

Sicuia, O.A., Grosu, I., Constantinescu, F., Voaideş, C., Cornea, C.P. (2015). Enzymatic and genetic variability in Bacillus spp. strains with plant beneficial qualities. AgroLife Scientific Journal, 4(2), 124-131.

Wu, Y., Zhou, J., Li, C., Ma, Y. (2019). Antifungal and plant growth promotion activity of volatile organic compounds produced by Bacillus amyloliquefaciens. MicrobiologyOpen, 8(8), 813. https://doi.org/10.1002/mbo3.813. 